\title{
An IPCC that listens: introducing reciprocity to climate change communication
}

\author{
Karl Dudman $^{1}$ (D) $\cdot$ Sara de Wit ${ }^{1}$ (DD \\ Received: 12 January 2021 / Accepted: 23 July 2021/ Published online: 7 September 2021 \\ (C) The Author(s) 2021
}

\begin{abstract}
As the epistemic hand in the UNFCCC'S political glove, the IPCC is charged with furnishing the global dialogues with 'reliable knowledge' on climate change. Much has been written about how this body of scientific information can be communicated more effectively to a diverse public, but considerably less so on the role communication might play in making the IPCC itself more receptive to alternative forms of contribution. Climate change communication remains centred on a unidirectional model that has helped climate science achieve greater public legibility, but so far not explored equivalent channels within institutional thinking for representing public and other non-scientific knowledges. Anticipating a new assessment report and major developments for the Paris Agreement, now is an opportunity to consider ambitious pathways to reciprocity in the IPCC's communication strategy. Drawing on interdisciplinary insights from social science literatures, we argue that communication is not only inseparable from knowledge politics in the IPCC, but that communication activities and research may prove key avenues for making the IPCC more inclusive. Recognising climate communication as a developed field of study and practice with significant influence in the IPCC, we present a framework for categorising communicative activities into those which help the panel speak with a more human voice, and those that help it listen receptively to alternative forms of knowledge. The latter category especially invites communicators to decouple 'epistemic authority' from 'scientific authority', and so imagine new forms of expert contribution. This is critical to enabling active and equitable dialogue with underrepresented publics that democratises climate governance, and enhances the public legitimacy of the IPCC.
\end{abstract}

Keywords Reciprocal communication · Epistemic hierarchies · Inclusive knowledge production · Environmental expertise

This article belongs to topical collection "Climate Change Communication and the IPCC", edited by Saffron O'Neill and Roz Pidcock.

Karl Dudman

karl.dudman@anthro.ox.ac.uk

Extended author information available on the last page of the article 


\section{Introduction}

In this positioning paper, we address some of the challenges facing the IPCC in its mission to expand and improve its communications by invoking the notion of reciprocity. In this year of stocktaking for climate politics, we see communication as a key avenue for increasing the IPCC's own ambition, fostering equitable conversations across diverse knowledges, sociocultural perspectives and publics. Though the IPCC does not itself wield decision-making power, its role in providing the epistemological foundation for policy discussions means the composition of its communications greatly influences what forms of knowledge receive representation in global climate politics, and civic discourse more broadly. Offering a view from the social sciences and humanities, we first summarise some longstanding concerns on the contingent construction of the natural sciences as sole spokesperson for climate change, and the negative effects of such a narrow framing on diverse public, lay or place-based knowledges worldwide. This 'representation dilemma'-based on discussions of knowledge politics from anthropology, Reception Studies, Science and Technology Studies (STS) and geography — overlaps considerably with communications studies' emphasis on cultural norms and the social life of science. Given its great success enabling climate science to speak with a more human voice (what we call speaking), we anticipate an influential role for communicators in aiding publics to answer back and be heard (listening). We present speaking and listening as a framework for evaluating communicative activities in terms of their balance of informational flows from science to society and society to science and policy. Arguing that climate communication has hitherto focused on speaking, we propose listening as an additional category that addresses the epistemological concerns of the 'representation dilemma', and asks what a communications paradigm that explores channels for non-scientific input within policyoriented bodies like the IPCC may look like.

Finally, bringing discussion back to IPCC, we consider some of the epistemological and organisational barriers to IPCC communication that speaks and listens, ultimately identifying its dual persona as an epistemic and scientific authority as prohibitive to transformational changes in response to the 'representation dilemma'. We nevertheless identify some key activities that may prove more feasible in the near term. These include learning from governance experiments in similar Global Environmental Assessments (GEA), expanding disciplinary representation in its Working Groups (WG), and reviewing how the nature of 'policy-relevant' knowledge changes in light of the UNFCCC's own pluralising agenda.

Crucially, we do not present here a blueprint for a new governance system (see e.g. Castree et al. 2021), but a new way of framing critical tensions in the current one that may help facilitate their resolution. In this new reciprocity framework, we see a helpful tool for thinking through the IPCC's opportunities and barriers to increasing its representative scope, and the role that climate communications could play in enabling this through advice and norm-setting activities.

\section{The representation dilemma: how science came to speak for climate}

The idea of a 'global climate', first emerging in the nineteenth century from the aggregation of localised meteorological records (Hulme 2017: 20), is 'an invention of modernity and the scientific mind' (28). Though climatic changes have long been registered culturally and at a local level (Endfield 2011), claims about its systemic nature have largely been constructed as 
beyond the scope of naked perception (Rudiak-Gould 2013), giving the natural sciences an authority to speak for climate that preceded its social visibility (Beck 1992). The possibility of reducing the climate to an abstract quantity of greenhouse gas emissions (Rayner 1995) or a 'global mean temperature' (Boykoff et al. 2010) made it a discrete 'object of government' (Rutland and Aylett 2008) to be negotiated at a diplomatic scale to match its own global dimensions (Miller 2004). By the late 1980s, computer-based modelling and global knowledge infrastructures shifted the very meaning of climate to a phenomenon almost exclusively characterised in global terms (Edwards 2001: 32-33).

Underpinned by this constructed monopoly on the definition of climate change emerged a hierarchy in the status of knowledge, with science as the predominant mode of existence (Latour 2013; Szerszynski and Urry 2010), set apart from 'local' knowledge and interpretive accounts of human experience (Hulme 2011; Castree et al. 2014). This purification process (Latour 2012), identified by critical scholars in a wide range of societal contexts beyond just climate change, resulted in dichotomies being formed between science and politics, and science and non-scientific forms of knowing climate (Jasanoff and Wynne 1998; Kempf 2017). The result is a great divide between the 'impersonal, apolitical and universal imaginary' posited by science and the 'subjective, situated and normative imaginations of human actors engaging with nature' (Jasanoff 2010: 233). These hierarchies become endemic within societies (Jasanoff 2005) but are also maintained by institutions through 'boundary work' that aims to preserve the credibility of science and its stable relationship with policy (Gieryn 1983; Beck and Mahony 2018). Within this epistemic order, science communication can easily run into a 'purification trap', employing models that impose one knowledge system onto another by removing local 'barriers' such as culture or religion in favour of a 'correct' (scientific) understanding of risk (Lazrus 2015: 59; Kempf 2017; Nunn 2017). But in non-western contexts where an enumerated climate 'normal' may have no currency as a baseline for recognising change (de Wit 2020), an exclusive appeal to globalist narratives can at best prove incommunicable, and at worst, do 'epistemological' and 'ontological' violence to place-based knowledges (de Wit 2017; Radcliffe et al. 2010: 102; Fair 2018; Ford et al. 2020; Dewan 2020).

In the climate change adaptation agenda, for example, the hegemony of the natural sciences has become visible in the 'human dimensions' debate, which has greatly influenced the conceptualisation of the three key terms: vulnerability, resilience and adaptation (Bassett and Fogelman 2013; Taylor 2015; Hastrup and Fog Olwig 2012). The apolitical and crisis framing of these concepts have rendered context-specific ways of 'living climate' (Crook and RudiakGould 2018: 2) less meaningful, particularly when they do not 'fit' climate model projections (Goldman et al. 2018: 5). Guided by a techno-managerial rationality, the prevailing 'adjustment' approach to adaptation has largely resulted in top-down solutions (Schipper 2007: 6; Eguavoen et al. 2015), empowering elites while denying overall agency to local communities (Orlove 2009: 131-132; Morchain 2018: 56; 6). Increasing cases can be found worldwide of techno-managerial adaptation solutions imposed at the expense of localised knowledge and needs (Klepp 2013; Klepp and Chavez-Rodriguez 2018: 11). For example, a large-scale embankment project implemented by the World Bank in Bangladesh to limit the effects of sea level rise disregarded generations of contextual knowledge about the natural flow of monsoon inundations in its expert assessment, resulting in avoidable flooding and dying rivers (Dewan 2020). Such injustices are real-world manifestations of the representation dilemma that can be redressed by incorporating reciprocal strategies of climate knowledge communication that centre around the question of what 'relevant knowledge' actually means (Dilling et al. 2019). 
A key goal identified by social scientists - but also variously in strands of scholarly activism (e.g. ecofeminist critique, see Israel and Sachs 2013) and non-western contexts (Hulme 2008: 8; Kempf 2020) — is thus finding a way out of the essentialised opposition between universal modern science versus non-scientific knowledge (Diemberger and Graf 2012: 233; Callison 2014). This is an objective increasingly engaged by activities in climate change communication. Rejecting the 'information deficit model', in which public disengagement is attributed to a lack of understanding (Nisbet and Scheufele 2009), communications research explores dynamic, intersecting networks of cultural and psychological factors that influence the circulation of information in society (Moser and Dilling 2011: 166). This portrayal of the public as diverse and complex rather than passive and credulous converges with critical interventions from Reception Studies on the 'active audience' (Livingstone 2019; de Wit and Haines forthcoming). Likewise, sensitivity to the translation of IPCC knowledge on its journey through society (Boykoff and Boykoff 2007; de Wit et al. 2018) engages founding questions in STS on how scientific authority is constructed and stabilised (Latour 1983).

This growing attention to the normative dimensions of societal engagements with climate has gradually eroded any meaningful separation of climate communication from knowledge politics. Given the hitherto success of communications research in humanising science dissemination (IPCC 2016), we thus anticipate an influential role for communicators in facilitating the flow of knowledge the other way. In the following, we outline a framework for categorising communicative activity. Incorporating work already done to make climate science speak with a more human voice, we add the new category of listening to reimagine communication as a reciprocal act.

\section{The speaking agenda}

A large majority of contemporary activities relating to climate communication focus on what we call speaking. Social scientists have argued for decades that the sciences cannot be understood as separate from society (Beck 1992; Latour 1999) but must 'come out to the street' (Carvalho 2007), engaging actively with their own political status (Pielke 2007) and representation (Wainwright and Mulligan 2013). Indeed, with its growing prominence, climate science increasingly has had to navigate the dangers of misrepresentation - whether deliberate (McCright and Dunlap 2003) or by misinterpretation (Hajer 2012). In trying to clarify and so protect the message of climate science, communication has provided an entry point for science's interactions with society.

The contemporary climate communicator's toolkit offers psychological models, heuristics and biases to make sense of public perceptions (Kahan 2014); it excavates the roles of narrative framing (Nisbet 2009), imagery (O'Neill and Nicholson-Cole 2009) and the media (Painter 2013) in making facts more or less resonant with diverse audiences. Rejecting the 'deficit model', these literatures foreground complex social contingencies like ideology (Moser 2016) and trust (Eiser et al. 2009) in determining people's responses to scientific information.

Such developments have done much to give climate science a more relatable public presence, providing the theoretical basis for important communication advice to scientists and the IPCC (Corner et al. 2018). They do not, however, address the representation dilemma outlined above, because they arguably only facilitate unidirectional communication: transmitting scientific conclusions to non-scientific audiences. The IPCC's own expert meeting on communication (IPCC 2016) appears to confirm this: recognising that science cannot simply 
be appended to an ignorant audience at the end of the fact-finding process $(6 ; 48)$, the 'broader' communication model nevertheless suggests that engaging with stakeholders' values (6) remains a one-way street, with the aim of "chang[ing] people's perceptions" (14). Insofar as these efforts identify the public as the subject in need of alteration, without questioning whether it may be a source as well as a destination for relevant facts, they belong to a type of communication that does not concern itself with the representation dilemma, and thus does not fully escape the deficit model.

\section{The listening agenda}

If climate communication that speaks asks 'How do we convey authoritative knowledge?', the question required to address the representation dilemma is 'What constitutes authoritative knowledge?' Clearly this allusion to a much wider cast of actors and knowledges means expanding the objectives of communication itself; no longer just amplifying and humanising science, but facilitating a more inclusive dialogue. Communication that listens is thus more challenging. It cannot be done via cosmetic changes to otherwise settled facts; it entails changes within systems and institutions and what they 'honour as knowledge' (Harding 1986: 24). A listening paradigm of communication investigates opportunities for nonscientific knowledges to communicate $u p$.

This activity is considerably more diffuse within the communication canon than speaking, but not unavailable. Research in public participation has long explored models of democratised, bi-directional decision-making (Peterson St-Laurent et al. 2020). This has influenced science communication projects with a specific lens of reciprocal education, such as the science museum in North Carolina facilitating public input in local flood resilience planning (Cawley 2021). Citizens' assemblies have been another focus among communicators for producing inclusive, trusted and robust decision-making based on distributed expertise (Corner 2020). Such activities tend to be highly localised and uncoordinated however, with influence barely reaching national, let alone global, scales (Dietz 2013). Elsewhere, Candis Callison's account of circumpolar knowledge politics (2014) documents the various channels through which place-based Inuit knowledges reach larger-scale political, scientific and public discourse. From literary non-fiction to representation in epistemic bodies like the Arctic Climate Impact Assessment (52), Callison details the diverse roles that Inuit communicators play in translating local knowledge to traditionally hegemonic audiences, rather than the other way round. The scope of these 'boundary-spanners' to assert non-scientific rationales has already been explored within the activities of the Intergovernmental Science-Policy Platform on Biodiversity and Ecosystem Services (IPBES) (Löfmarck and Lidskog 2017: 27), illustrating the interconnectedness of communication and knowledge politics, and warranting further research by communicators.

In imagining the role that communication can play in establishing new spaces for listening within the IPCC, these examples may provide a basis for a broader class of communicative action and actors, making publics relevant to policy much as they have science to publics. It is worth acknowledging that much communication activity we have classed as speaking is built on detailed and patient interactions with specific communities - a form of listening. When done merely to deliver the same message with a more familiar voice however, or as an instrument to 'co-produce' 'usable' climate and weather services (Daly and Dilling 2019), it is not the same as giving these communities representation alongside scientists in decision- 
making (e.g. see the "Rising Voices" initiative, Maldonado and Lazrus 2019). We thus label this instrumental listening, in opposition to the receptive listening described here. Oftentimes instrumental listening can become receptive listening merely by changing its application. Detailed studies of public climate knowledge (e.g. Marshall et al. 2018) can either be used to deliver science to the public dressed in 'the look of community' (Rose 1999), or it can be branded 'policy-relevant' and travel upwards, informing policy-makers on what matters to the communities their decisions fall upon. Communicators already play a significant advisory role in the public-science-policy nexus (Corner et al. 2018; IPCC 2016), and could conceivably perform the sort of boundary-bridging envisioned by Hulme (2008) as restoring humanity's voice in climate discourse.

Listening thus seeks to create new spaces for reciprocity that previously did not exist. If climate change communication is to truly escape the deficit model, it must itself explore new avenues for dialogue that is receptive rather than instrumental; it must listen to more than science for knowledge worth communicating, and challenge its institutional collaborators to reciprocate the openness they seek to cultivate in public audiences.

\section{Discussion: rethinking communication for the IPCC}

The IPCC is a communicative institution. Though it lacks executive powers of its own, its unparalleled mandate to provide global climate decision-making with relevant knowledge (Hulme 2010) gives its outputs the tacit and prescriptive power to enable certain political futures and foreclose others (Beck and Mahony 2017). 'How' and 'what' to communicate are thus questions to be addressed in tandem; an IPCC that speaks and listens is one adept at conversing with society not only for the purpose of making itself understood but devising ever better and more representative assessments of the global state of climate change. Receptive to cultural as well as scientific knowledges, it would be able to convey not just the atmospheric effects of burning gas, for example, but the differential cultural roles these emissions play for those who burn it for 'subsistence' and those for 'luxury' (Agarwal and Narain 2019), and the particular social histories that originated such inequalities. The global ecology of social relationships with climate change is easily as complex and dynamic as the material and chemical forces that drive that change, yet this is not evident in the IPCC's rendering of 'relevant knowledge' (Hulme 2008). What the listening agenda adds is new spaces for asking 'who is entitled to speak on behalf of nature on the world stage' (Miller and Edwards 2001: 11).

This is not to downplay the structural barriers that prohibit these changes. The IPCC's findings are legitimised by their utility to world governments; its political and epistemic authority is not self-defined but bound by a mutually constitutive relationship between science and policy (Miller 2004; Pearce et al. 2018). The IPCC thus exists within politicised and carefully maintained boundaries, not easily shifted (Beck and Mahony 2018; Shaw and Robinson 2004). Though we do not go as far as to advocate redrawing these boundaries between knowledge and action, even reforming the execution of tasks within the IPCC's existing remit requires the consent of participating governments. Beyond questions of governance, diversifying social and disciplinary representation also presents deep epistemological challenges to principles of consensus (Beck et al. 2014) and enumeration (Hulme 2010) that have characterised the IPCC project for decades. As the representation dilemma attests, the IPCC was born into a social order that privileges scientific knowledge. Conceived with an 
explicitly scientific purpose, that social order has nevertheless been comprehensively encultured within the IPCC's 'institutional epistemology' (Borie et al. 2021), creating a lasting sticking point among calls for its democratisation (Obermeister 2017).

The demands of receptive listening clearly chafe against the political and epistemological constraints of the IPCC, but it is precisely this friction that exposes a tension between the IPCC's two identities: as procurer of relevant climate knowledges, and as a fundamentally scientific institution. Epistemic authority is not the same as scientific authority, yet their treatment as unproblematically synonymous is a conflation that predates the IPCC and which it has come to embody (Hulme 2010). Listening, by reopening this distinction, makes conceptual space for non-scientific knowledges that previously could not exist. In this year of stocktaking, we present the 'reciprocity framework' as an instrument for extending the renewed ambition in global climate politics to its communication, and for imagining new roles for communicators in doing so. We envision this framework not to prescribe specific changes to the IPCC, but as an analytical and heuristic tool ratcheting the ambitions of communication. Nevertheless, having outlined how communicators might expand their scope, we here identify some possible avenues for exploration within the IPCC framework.

The IPCC continues to operate within the same ethos of consensus-based multilateralism as it did in 1988 (Beck et al. 2014), in which agreement is the currency of progress. The UNFCCC has since moved away from this approach (Kuyper et al. 2018), embracing a more devolved and heterogeneous cast of actors-from global protest movements to local businesses - as key contributors to the global effort. Initiatives such as the Talanoa Dialogues and Marrakesh Partnership have sought to rehumanise the diplomatic space with storytelling and community action. Notwithstanding its organisational constraints, the IPCC retains significant autonomy in its framing of issues, and has used the "narrative structure of its scientific assessments' as an instrument for influencing global discourse before (Miller 2007: 341). The IPCC might therefore consider how the nature of 'policy-relevant' knowledge changes in light of developments in the UNFCCC.

Precedents also exist among other GEAs, similarly navigating knowledge politics despite organisational constraints. A particular hub of scholarship has formed around IPBES, seeking more inclusive institutional definitions of expertise as an alternative to the hierarchical IPCC model (Díaz-Reviriego et al. 2019; Montana 2017; Borie et al. 2021). Though not without its own shortcomings, IPBES's experiments in democratised knowledge production may now return lessons for the IPCC (Beck and Mahony 2018: 9). More simply, the IPCC could substantially scale its own existing activities in targeted areas. Its WG2 on 'impacts, adaptation and vulnerability' in particular has begun expanding its scope beyond technical subjects, even incorporating 'epistemology and different forms of climate-related knowledge and data, including indigenous and practice-based knowledge' in its remit for the 6th assessment report (IPCC 2021: 31). This is hugely promising, but with science and economics still occupying a significant majority of disciplinary representation (for more see Obermeister 2017: 82; Castree et al. 2021: 59) and thus still articulating the kinds of questions that are relevant, there is a way to go. Nevertheless, the IPCC already bases its assessments on existing, not novel, research; with a more expansive scope, it could access an enormous standing army of diverse contributions within social sciences and the humanities (Denis and Moser 2015).

Finally, we do not suggest that listening should replace or subordinate the speaking agenda. Likewise, though in an epistemologically cosmopolitan IPCC the relative primacy of the sciences would of course decline, this would be as a result of recognising new forms of expert contribution rather than in any way diminishing the value of science; this is a 'science and' 
argument, not a 'science or' one. Arguing always for a complementary relationship between approaches, we envision an IPCC that speaks and listens in all the languages of science and society. Indeed, we actually anticipate that opening up the IPCC to non-scientific perspectives makes speaking easier. As long as climate science is the sole voice granted authority to speak for climate change, it will be incumbent on scientists to be overseers of public and political sensemaking on the issue (Pearce et al. 2017). Striking a balance between accessibility and scientific credibility is an ongoing concern for the IPCC (2016:3) and historically has proven difficult to achieve (Hajer 2012). Enculturing a humility that recognises the limits of scientific sight and the abundance of alternative ways of knowing that can speak with authority beyond those limits (Jasanoff 2007) could liberate science from the burden of omniscience.

Any field stretched beyond its own disciplinary parameters is vulnerable to distortion. Just as simplification strains the integrity of climate science, so too can employing the language of numbers to speak for human dimensions of climate change become a compromise too far. Thus, in speaking and listening, we present a new brand of communicative thinking in support of the IPCC that makes space for social complexity within the machinery of the institution, and gives it a pair of ears to accompany its ever-strengthening voice.

Acknowledgements We wish to thank Javier Lezaun and Jerry Ravetz for their helpful feedback on the first draft. We also thank the 4 reviewers for their detailed and constructive comments.

Author contribution Contributions to planning, research, writing, solicitation of feedback, editing, and most formatting were made in equal measure by both authors (KED and SDW). Majority amendments to drafts two and three are made by KED. Final edits to formatting were performed by KED.

Funding Karl Dudman, not applicable; Sara de Wit, FATHUM project NERC/FCDO, grant number NE/ P000525/1.

Data availability Not applicable.

Code availability Not applicable.

\section{Declaration}

Ethical approval Not applicable.

Consent to participate Not applicable.

Consent to publish Not applicable.

Conflict of interest The authors declare no competing interests.

Open Access This article is licensed under a Creative Commons Attribution 4.0 International License, which permits use, sharing, adaptation, distribution and reproduction in any medium or format, as long as you give appropriate credit to the original author(s) and the source, provide a link to the Creative Commons licence, and indicate if changes were made. The images or other third party material in this article are included in the article's Creative Commons licence, unless indicated otherwise in a credit line to the material. If material is not included in the article's Creative Commons licence and your intended use is not permitted by statutory regulation or exceeds the permitted use, you will need to obtain permission directly from the copyright holder. To view a copy of this licence, visit http://creativecommons.org/licenses/by/4.0/. 


\section{References}

Agarwal A, Narain S (2019) Global warming in an unequal world: a case of environmental colonialism. India in a warming world. Oxford University Press, Delhi

Bassett TJ, Fogelman C (2013) Déjà vu or something new? The adaptation concept in the climate change literature. Geoforum 48:42-53

Beck U (1992) Risk society : towards a new modernity. Sage, London

Beck S, Mahony M (2017) The IPCC and the politics of anticipation. Nat Clim Chang 7:311-313

Beck S, Mahony M (2018) The IPCC and the new map of science and politics. WIREs Clim Change 9:e547

Beck S, Borie M, Chilvers J, Esguerra A, Heubach K, Hulme M, Lidskog R, Lövbrand E, Marquard E, Miller C, Nadim T, Neßhöver C, Settele J, Turnhout E, Vasileiadou E, Görg C (2014) Towards a reflexive turn in the governance of global environmental expertise: the cases of the IPCC and the IPBES. Gaia 23:80-87

Borie M, Mahony M, Obermeister N, Hulme M (2021) Knowing like a global expert organization: comparative insights from the IPCC and IPBES. Glob Environ Chang 68:102261

Boykoff MT, Boykoff JM (2007) Climate change and journalistic norms: a case-study of US mass-media coverage. Geoforum 38:1190-1204

Boykoff MT, Frame D, Randalls S (2010) Discursive stability meets climate instability: a critical exploration of the concept of 'climate stabilization' in contemporary climate policy. Glob Environ Chang 20:53-64

Callison C (2014) How climate change comes to matter: the communal life of facts. Duke University Press, Durham

Carvalho A (2007) Ideological cultures and media discourses on scientific knowledge: re-reading news on climate change. Public Underst Sci 16:223-243

Castree N, Adams WM, Barry J, Brockington D, Büscher B, Corbera E, Demeritt D, Duffy R, Felt U, Neves K, Newell P, Pellizzoni L, Rigby K, Robbins P, Robin L, Rose DB, Ross A, Schlosberg D, Sörlin S et al (2014) Changing the intellectual climate. Nat Clim Chang 4:763-768

Castree N, Bellamy R, Osaka S (2021) The future of global environmental assessments: making a case for fundamental change. Anthropocene Rev 8:56-82

Cawley M (2021) Most people aren't climate scientists. We should talk about climate change anyway. Discover Magazine. https:/www.discovermagazine.com/environment/most-people-arent-climate-scientists-weshould-talk-about-climate-change. Accessed 12 May 2021

Corner A (2020) Covid, climate Change \& Citizens' assemblies: the critical role of deliberation for planned transitions. Climate Outreach. https:/climateoutreach.org/covid-climate-change-citizens-assemblies/. Accessed 12 May 2021

Corner A, Shaw C, Clarke J (2018) Principles for effective communication and public engagement on climate change: a handbook for IPCC authors. Climate Outreach, Oxford

Crook T, Rudiak-Gould P (2018) Introduction to: Pacific climate cultures: living climate change in Oceania. In: Pacific Climate Cultures. De Gruyter, Warsaw/Berlin, pp 1-20

Daly M, Dilling L (2019) The politics of "usable" knowledge: examining the development of climate services in Tanzania. Clim Chang 157:61-80

de Wit S (2017) Love in times of climate change: how an idea of adaptation to climate change travels to northern Tanzania, Universität zu Köln

de Wit S (2020) To see or not to see: on the 'absence' of climate change (discourse) in Maasailand, northern Tanzania. In: Environmental change and African societies. Brill, Leiden, Boston, pp 23-47

de Wit S, Haines S (forthcoming) Climate change reception studies in anthropology. WIREs Clim Change

de Wit S, Pascht A, Haug M (2018) Translating climate change: anthropology and the travelling idea of climate change. Sociologus 68(1):1-20

Denis M, Moser SC (2015) IPCC: calling social scientists of all kinds. Nature 521:161-161

Dewan C (2020) Climate change as a spice: brokering environmental knowledge in Bangladesh's development industry. Ethnos:1-22

Díaz-Reviriego I, Turnhout E, Beck S (2019) Participation and inclusiveness in the intergovernmental sciencepolicy platform on biodiversity and ecosystem services. Nat Sustain 2

Diemberger H, Graf HF (2012) Snow-Mountains on the Tibetan plateau: powerful proxies across different modalities of climate knowledge. In: Diemberger et al communicating climate knowledge: proxies, processes, politics current anthropology 53(2):233-236

Dietz T (2013) Bringing values and deliberation to science communication. Proc Natl Acad Sci 110:14081-14087

Dilling L, Prakash A, Zommers Z, Ahmad FSN, de Wit S, Nalau J, Daly M, Bowsman K (2019) Is adaptation success a flawed concept? Nat Clim Chang 9:570-574

Edwards PN (2001) Representing the global atmosphere: computer models, data, and knowledge about climate change. In: Edwards PN, Miller CA (eds) Changing the atmosphere: expert knowledge and environmental governance. MIT Press, Cambridge, Mass. London, pp 31-66 
Eguavoen I, Schulz K, de Wit S, Weisser F, Müller-Mahn D (2015) Political dimensions of climate change adaptation. Conceptual reflections and African examples. In: Leal Filho W (ed) Handbook of climate change adaptation. Springer, Berlin/Heidelberg, pp 1183-1198

Eiser J, Stafford T, Henneberry J, Catney P (2009) "Trust me, I'm a scientist (not a developer)": perceived expertise and motives as predictors of Trust in Assessment of risk from contaminated land. Risk Anal 29: 288-297

Endfield G (2011) Reculturing and particularizing climate discourses: weather, identity, and the work of Gordon Manley. Osiris 26:142-162

Fair H (2018) Three stories of Noah: navigating religious climate change narratives in the Pacific Island region. Geo: Geography and Environment

Ford JD, King N, Galappaththi EK, Pearce T, McDowell G, Harper SL (2020) The resilience of indigenous peoples to environmental change. One Earth 2:532-543

Gieryn TF (1983) Boundary-work and the demarcation of science from non-science: strains and interests in professional ideologies of scientists. Am Sociol Rev 781-795

Goldman MJ, Turner MD, Daly M (2018) A critical political ecology of human dimensions of climate change: epistemology, ontology, and ethics. WIREs Clim Change 9(4):1-15

Hajer MA (2012) A media storm in the world risk society: enacting scientific authority in the IPCC controversy (2009-10). Crit Policy Stud 6:452-464

Harding SG (1986) The science question in feminism. Cornell University Press, Ithaca

Hastrup K, Fog Olwig K (eds) (2012) Climate Change and Mobility: Global Challenges to the Social Sciences. Cambridge University Press

Hulme M (2008) Geographical work at the boundaries of climate change. Trans Inst Br Geogr 33:5-11

Hulme M (2010) Problems with making and governing global kinds of knowledge. Glob Environ Chang 20: $558-564$

Hulme M (2011) Meet the humanities. Nat Clim Chang 1:177-179

Hulme M (2017) Climate change and the significance of religion. Econ Polit Wkly 52:14-17

IPCC (2016) In: Lynn J, Araya M, Christophersen Ø, El Gizouli I, Hassol SJ, Konstantinidis EM, Mach KJ, Meyer LA, Tanabe K, Tignor M, Tshikalanke R, van Ypersele J-P (eds) Meeting report of the intergovernmental panel on climate change expert meeting on communication. World Meteorological Organization, Geneva, p 229

IPCC (2021) AR6 climate change 2021: impacts, adaptation and vulnerability - IPCC. In: IPCC https://www. ipcc.ch/report/sixth-assessment-report-working-group-ii/

Israel AL, Sachs C (2013) A climate for feminist intervention: feminist science studies and climate change. Research, action and policy: addressing the gendered impacts of climate change. Springer, pp 33-51

Jasanoff S (2005) Designs on nature : science and democracy in Europe and the United States. Princeton University Press, Princeton, N.J. Oxford

Jasanoff S (2007) Technologies of humility. Nature 450:33

Jasanoff S (2010) A new climate for society. Theory Cult Soc 27:233-253

Jasanoff S, Wynne B (1998) Science and decision making. In: Rayner S, Malone EL (eds) Human choice and climate change. Battelle Press, Columbus Ohio, pp 1-88

Kahan DM (2014) Making climate-science communication evidence-based — all the way down. Culture, Politics and Climate Change, Routledge

Kempf W (2017) Climate change, Christian religion and songs: revisiting the Noah story in the Central Pacific. In: Dürr E, Pascht A (eds) Environmental transformations and cultural responses. Palgrave Macmillan, New York, NY, pp 9-48

Kempf W (2020) Introduction: climate change and Pacific Christianities. Anthropol Forum 30:215-232

Klepp S (2013) Small Island states and the new climate change movement. Routledge handbook of the climate change

Klepp S, Chavez-Rodriguez L (2018) A critical approach to climate change adaptation. Discourses, policies, and practices. Routledge, London

Kuyper J, Schroeder H, Linner B-O (2018) The evolution of the UNFCCC. Annu Rev Environ Resour 43:343-368

Latour B (1983) Give me a laboratory and I will raise the world. En Science observed: perspectives on the social study of science (pp. 141-170). Sage Publications, Beverly Hills

Latour B (1999) Pandora's hope: essays on the reality of science studies. Harvard University Press, Cambridge, Mass. London

Latour B (2012) We have never been modern. Harvard University Press, Cambridge, Mass. London

Latour B (2013) An inquiry into modes of existence: an anthropology of the moderns, Catherine porter (tr.). Harvard University Press, Cambridge, Mass, London

Lazrus H (2015) Risk perception and climate adaptation in Tuvalu: a combined cultural theory and traditional knowledge approach. Hum Organ 74:52-61 
Livingstone S (2019) Reception studies. The Blackwell Encyclopedia of Sociology, pp 1-3

Löfmarck E, Lidskog R (2017) Bumping against the boundary: IPBES and the knowledge divide. Environ Sci Pol 69:22-28

Maldonado J, Lazrus H (2019) A story of "rising voices" and intercultural collaboration. Pract Anthropol 41:34 37

Marshall G, Bennett A, Clarke J (2018) Communicating climate change and energy in Alberta-Alberta narratives project. Climate Outreach, Oxford

McCright AM, Dunlap RE (2003) Defeating Kyoto: the conservative movement's impact on U.S. climate change policy. Soc Probl 50:348-373

Miller CA, Edwards PN (eds) (2001) Changing the atmosphere: expert knowledge and environmental governance. MIT Press, Cambridge, Mass. London

Miller CA (2004) Climate science and the making of a global political order. States of knowledge: The coproduction of science and social order 317

Miller C (2007) Democratization, international knowledge institutions, and global governance. Governance: an international journal of policy, administration, and institutions 20:325-357

Montana J (2017) Accommodating consensus and diversity in environmental knowledge production: achieving closure through typologies in IPBES. Environ Sci Pol 68:20-27

Morchain D (2018) Rethinking the framing of climate change adaptation. Knowledge, power and politics. In: Klepp S, Chavez-Rodriguez L (eds) A critical approach to climate change adaptation: discourses, Policies and Practices, pp 55-73

Moser SC (2016) Reflections on climate change communication research and practice in the second decade of the 21st century: what more is there to say? Wiley Interdiscip Rev Clim Chang 7:345-369

Moser SC, Dilling L (2011) Communicating climate change: closing the science-action gap. The Oxford handbook of climate change and society:161-174

Nisbet MC (2009) Communicating climate change: why frames matter for public engagement. Environ Sci Policy Sustain Dev 51:12-23

Nisbet MC, Scheufele DA (2009) What's next for science communication? Promising directions and lingering distractions. Am J Bot 96:1767-1778

Nunn P (2017) Sidelining god: why secular climate projects in the Pacific Islands are failing. The Conversation. Retrieved from http://theconversation.com/sidelining-god-why-secular-climate-projects-in-the-pacificislands-are-failing-77623

Obermeister N (2017) From dichotomy to duality: addressing interdisciplinary epistemological barriers to inclusive knowledge governance in global environmental assessments. Environ Sci Pol 68

O'Neill S, Nicholson-Cole S (2009) "Fear Won't do it": promoting positive engagement with climate change through visual and iconic representations. Sci Commun 30:355-379

Orlove B (2009) The past, the present and some possible futures of adaptation. In: Adger NW, Lorenzoni I, O'Brien K (eds) Adapting to climate change: thresholds, values, governance. Cambridge University Press, pp 129-163

Painter J (2013) Climate change in the media: reporting risk and uncertainty. Reuters Institute for the Study of Journalism

Pearce W, Grundmann R, Hulme M, Raman S, Hadley Kershaw E, Tsouvalis J (2017) Beyond counting climate consensus. Environ Commun 11:723-730

Pearce W, Mahony M, Raman S (2018) Science advice for global challenges: Learning from trade-offs in the IPCC. Environ Science \& Policy 80:125-131

Peterson St-Laurent G, Hoberg G, Sheppard SRJ, Hagerman SM (2020) Designing and evaluating analyticdeliberative engagement processes for natural resources management. Elementa-Sci Anthrop 8:8

Pielke RA Jr (2007) The honest broker: making sense of science in policy and politics. Cambridge University Press, Cambridge

Radcliffe SA, Watson EE, Simmons I, Fernández-Armesto F, Sluyter A (2010) Environmentalist thinking and/in geography. Prog Hum Geogr 34:98-116

Rayner S (1995) Governance and the global. In: Global governance: ethics and economics of the world order, p 60

Rose N (1999) Powers of freedom: reframing political thought. Cambridge University Press

Rudiak-Gould P (2013) "We have seen it with our own eyes": why we disagree about climate change visibility. Weather Clim Soc 5:120-132

Rutland T, Aylett A (2008) The work of policy: actor networks, governmentality, and local action on climate change in Portland, Oregon. Environ Plan D Soc Space 26:627-646

Schipper EL (2007) Climate change adaptation and development: exploring the linkages. Tyndall Centre for Climate Change Research, p WP107

Shaw A, Robinson J (2004) Relevant but not prescriptive: science policy models within the IPCC. Philos Today 48:84-95 
Szerszynski B, Urry J (2010) Changing climates: introduction. Theory Cult Soc 27:1-8

Taylor M (2015) The political ecology of adaptation: livelihoods, agrarian change and the conflicts of development. Routledge, New York

Wainwright J, Mulligan M (2013) Environmental modelling [electronic resource]: finding simplicity in complexity. Wiley, Chichester [England], Hoboken, N.J

Publisher's note Springer Nature remains neutral with regard to jurisdictional claims in published maps and institutional affiliations.

\section{Affiliations}

\section{Karl Dudman ${ }^{1} \cdot$ Sara de Wit ${ }^{1}$}

1 Institute for Science, Innovation and Society (InSIS), University of Oxford, Oxford, UK 